\title{
EFFECT OF FENUGREEK SEEDS ON SOME PHYSIOLOGICAL CHARACTERS IN BROILER BREEDERS MALES
}

\author{
S. Y. Abdul-Rahman
}

Animal Resources Dept. College of Agric. \& Forestry Mosul Univ., Iraq

\begin{abstract}
This study aimed to investigate the effects of Fenugreek seeds treatment ( Trigonella foenum graecum ) on blood parameters of broiler breeder males , the study include 4 groups ( 9 Arbor Acres cock, each ) 65 weeks aged, 1group : Control: reared on standard ration. 2- The $1^{\text {st }}$ : reared on standard ration ,supplemented $10 \mathrm{gm} / \mathrm{kg}$ ration once weekly

2 - The $2^{\text {nd }}:$ reared on standard ration, supplemented $10 \mathrm{gm} / \mathrm{kg}$ ration twice weekly .4- The $3^{\text {rd }}:$ reared on standard ration, supplemented $10 \mathrm{gm} / \mathrm{kg}$ ration daily. The treatment continue for 8 weeks .Fenugreek seeds improve blood picture as compared with control represented by the significant increase in the RBCs ( 2.55 and 2.92 million / mm3 ) and hemoglobin concentration ( 12.51 and $14.43 \mathrm{gm} / \mathrm{dl}$ ) and PCV ( 31.8 and $34.26 \%$ ) in the2nd and 3rd group, also a significant increase in the thrombocytes count $(15002,17272$ and $21553 / \mathrm{mm} 3)$ in the $1 \mathrm{st}, 2 \mathrm{nd}$ and $3^{\text {rd }}$ groups, this was reflected on the significant reduction of the clotting time in the 3rd group ( 53.33 seconds ), treatment has no effects on the T.WBC, on the other hand, there was a significant decrease in the Hetrophils $\%$ in the2nd and 3rd groups ( $23 \%$ and $19.44 \%$ ), a significant increase in lymphocytes \% in the 3rd group $(72.33 \%)$ and a significant decrease in the Hetrophils : Lymphocytes in the3rd and 2nd groups( 34.0 and $26.44 \%$ ). Treatment also causes a significant decrease in serum glucose levels in the 2nd and 3rd groups ( 264.02 and 229.01 $\mathrm{mg} / \mathrm{dl})$, cholesterol level in the $3 \mathrm{rd}(134.71 \mathrm{mg} / \mathrm{dl})$ and triglycerides level in the 1st ,2nd and 3rd groups ( 160.88 and 150.84 and $120.38 \mathrm{mg} / 100 \mathrm{ml}$ ) respectively . In general, the study revealed that Fenugreek seeds improve some blood characters in advance aged broiler breeder males.
\end{abstract}

\section{INTRODUCTION}

The big advances in poultry industry inorder to reach the marketing weight of broilers in 35 days( wepruk and Church,2003 ),causes a reduction in the immunity of birds and their resistance to diseases (Saif etal., 2003),also, this leads to an increase in the incidence of metabolic disorders as asitis, fatty liver haemorrhagic syndrome, skeleton disturbances and leg abnormalities (Gonzalez etal., 2000;Alkattan,2006 ).On the other hand ,many diseases and metabolic disorders were accompanied with a disturbance in the antioxidant status, and in the recent years there is a great attention with the plants and herbs that posses an antioxidant activity (Abdul-Rahman and Alkattan,2006 ;Taha,2008 ) inorder to determine their role in the reduction and/or protection form reactive oxygen species. In poultry production, broiler breeder males are important source of supplying broiler fields with chicken, and due to nature of nutritional and management programs, they were subjected to an increased risk of oxidative stress which affect also the physiological

Received $13 / 6 / 2012 \quad$ accepted $1 / 10 / 2012$ 
( Salah,2008) and reproductive performance Suria,1998) of that broiler breeder males .Recently, Abdul - Rahman etal.,( 2010 ) investigate the role of Fenugreek seeds supplentation to the ration of aged broiler breeder males in activation of reproductive performance and improving semen quality inorder to elongate their productive age. Also Mohammad,(2012) and Ahmad and Mohammad,(2012) use fenugreek seeds to improve their reproductive the performance in aged laying breeders( Isa Brown ), and Abdulrahman and Alobaidy ( 2012) and Alobaidy, (2012 ), also use fenugreek seeds to enhance the productive and physiological performance of aged laying breeders ( Isa brown ). This study aimed to investigate the effects of Fenugreek seeds on some physiological and biochemical parameters of aged broiler breeder males .

\section{MATERIALS AND METHODS}

The study was conducted on 36 Arbor Acres cocks ( 65 weeks aged), which divided randomly into 4 groups ( 9 birds each ). The treatment continued for 8 weeks with Fenugreek seeds( Trigonella foenum gracum ) which belongs to the family Leguminosae . Ration ( $15.5 \%$ protein and $2825 \mathrm{Kcal} / \mathrm{Kg}$ ) was formulated according to NRC( 1994 ) and supplied daily for the birds ( $136 \mathrm{gm} / \mathrm{bird} /$ day ) .

-Treatments:-

$1^{\text {st }}$ group: reared on standard ration (control).

$2^{\text {nd }}$ group ; reared on standard ration supplemented with 10 gm Fenugreek seeds powder / kg ration once weekly .

$3^{\text {rd }}$ group ; reared on standard ration supplemented with 10 gm Fenugreek seeds powder $/ \mathrm{kg}$ ration twice weekly .

$4^{\text {th }}$ group ; reared on standard ration supplemented with 10 gm Fenugreek seeds powder $/ \mathrm{kg}$ ration daily .

\section{-Collection of blood samples :}

At the end of the $8^{\text {th }}$ week of treatment blood samples were collected from wing vein, blood was divided into 2 parts, one with anticoagulanto (EDTA ) and used for blood picture examination, the other part ( without anticoagulant ) was used to separate the serum which stored at $\left(-20 \mathrm{C}^{\circ}\right)$ and used for determination of biochemical parameters.

\section{-Measurements :}

Total red blood cells count ( RBC ), total white blood cells count (WBC) and differential leucocytes were measured according to Campbell, ( 1995 ).Hemoglobin concentration ( $\mathrm{Hb}$ ), Packed cell volume ( PCV ) and Clotting time were measured according to Jain, ( 1986 ) .Thrombocytes count according to Campbell, ( 1995 ) by the use of blood slide stained with Wright's stain and the total thrombocytes was determined according to equation :

Estimated Thrombocytes count $/ \mathrm{mm}^{3}=\frac{\text { AverageNo.ofthrombocyte } \sin \text { 5 fields }}{1000} \times 3.500 .000$

Then the reading were corrected when the PCV reading are outside the range of $(40-50 \%)$ by the use of the equation : 
Corrected thrombocytes count $/ \mathrm{mm}^{3}=$ thrombocy tes count $\times \frac{\text { observed PCV }}{\text { normal PCV }}$

\section{* Normal PCV $=45$}

Serum glucose, triglycerides and cholesterol were determined by the use of enzymatic test kits ( Bio lab, France ).

-Statistical analysis : was done by of one way analysis of variance , and specific groups differences were determined by Duncan s multiple range test at $\mathrm{p} \leq 0.05$ significant level by using SAS program ( 2000 ).

\section{RESULTS AND DISCUSSION}

The Fenugreek seeds treatment enhances the erythropoiesis as shown by the significant increase in the $\mathrm{RBC}_{\mathrm{s}}, \mathrm{Hb}$ concentration and PCV\% specially in the $3^{\mathrm{rd}}$ and $4^{\text {th }}$ groups as compared with the control ( Table 1) also treatments causes a significant increase in the total thrombocyte counts which directly proportionate with the frequency of treatment. Also daily Fenugreek treatment improve significantly the clotting time as compared with control group ( table 1 ).this improvement in erythropoisis may be related to the enhancement of antioxidant activity in $\mathrm{RBC}_{\mathrm{s}}$ ( Jain,1989) revealed that the metabolic activities of the $\mathrm{RBC}_{\mathrm{s}}$ produces Free radicals that destroy $\mathrm{Hb}$ which precipitated as Heinz bodies and causes the hemolysis of $\mathrm{RBC}_{\mathrm{s}}(\mathrm{Taha}, 2008)$ showed that the experimentally induced oxidative stress in broiler breeder males causes a deterioration in antioxidant status in the testis and seminal plasma as represented in the reduction of glutathione (GSH ) and the elevation of malondialdehyde ( MDA ), on the other hands , many studies like ( Alkattan ,2006; Taha,2008 ) revealed that Fenugreek seeds possess antioxidant activity which increase the stability of RBC membranes through the formation of fatty complexes in the cell membranes that prevent or reduce the Free radicals effects (Erin etal.,1984), this was reflected in an increase in the $\mathrm{RBC}_{\mathrm{s}}$, and also on increase in $\mathrm{Hb}$ and $\mathrm{PCV} \%$ due to the presence of significant positive correlation between these parameters ( Salah, 2008 ). Ditto ( Sturkie, 2000 ) suggest that the thrombocytes are cells belonging to the erythrocyte series and this explain the it s parallel increase with the increase in $\mathrm{RBC}_{\mathrm{s}}$ this will go in agreement with Salah ( 2008 ) who revealed a positive significant correlation between $\mathrm{RBC}_{\mathrm{s}}$ and thrombocytes Ditto, (Salah, 2008 ) revealed a negative significant correlation between thrombocytes and clotting time in broiler breeders males treated with fenugreek seeds .

Table 1: Effect of Fenugreek seeds on some biochemical parameters in broiler breeders male serum.

\begin{tabular}{|l|c|c|c|c|c|}
\hline \multicolumn{1}{|c|}{ Treatments } & $\begin{array}{c}\text { RBCs } \\
\text { Million/mm }\end{array}$ & $\begin{array}{c}\text { Hb } \\
\text { gm/100ml }\end{array}$ & $\begin{array}{c}\text { PCV } \\
\%\end{array}$ & $\begin{array}{c}\text { Thrombocytes } \\
\text { Cell/ } \mathrm{mm}^{3}\end{array}$ & $\begin{array}{c}\text { Clotting time } \\
\text { sec }\end{array}$ \\
\hline Control & $2.31^{\mathrm{c}} \pm 0.05$ & $11.10^{\mathrm{c}} \pm 0.36$ & $29.48^{\mathrm{c}} \pm .42$ & $13515.56^{\mathrm{d}} \pm 218.78$ & $73.33^{\mathrm{a}} \pm 3.90$ \\
\hline $\begin{array}{l}\text { Fenugreek } \\
\text { Once weekly }\end{array}$ & $2.43^{\mathrm{bc}} \pm 0.05$ & $11.97^{\mathrm{bc}} \pm 0.31$ & $30.06^{\mathrm{c}} \pm 0.33$ & $15002.78^{\mathrm{c}} \pm 474.83$ & $65.00^{\mathrm{ab}} \pm 5.00$ \\
\hline $\begin{array}{l}\text { Fenugreek } \\
\text { Twice weekly }\end{array}$ & $2.55^{\mathrm{b}} \pm 0.05$ & $12.51^{\mathrm{b}} \pm 0.33$ & $31.80^{\mathrm{b}} \pm 0.50$ & $17272.89^{\mathrm{b}} \pm 385.91$ & $63.33^{\mathrm{ab}} \pm 3.33$ \\
\hline $\begin{array}{l}\text { Fenugreek } \\
\text { Daily }\end{array}$ & $2.92^{\mathrm{a}} \pm 0.07$ & $14.43^{\mathrm{a}} \pm 0.33$ & $34.26^{\mathrm{a}} \pm 0.42$ & $21553.22^{\mathrm{a}} \pm 756.56$ & $53.33^{\mathrm{b}} \pm 4.40$ \\
\hline
\end{tabular}

$* \pm=$ Standard error $/ \mathrm{n}=9 . *$ Small English letters vertically mean their is a significant difference at $\mathrm{p}<0.05$ significant level 
( Table - 2 ) showed that fenugreek seeds causes a reduction in heterophils $\%$ and an increase in the Lymphocyte \%, and this will reflected in the improvement in the heterophils : Lymphocyte ratio ( stress index ) specially in the $3^{\text {rd }}$ and $4^{\text {th }}$ group of the treatments .The WBC usually affected by stress factors ( Saeed, 1998 ) showed an increase in the $\mathrm{WBC}_{\mathrm{s}}$ on the stressed local cocks, stress factors stimulate the ACTH secretion from pituitary, which causes the secretion of corticosterone from adrenal cortex ( Siegel, 1980 ) which causes an increase in $\mathrm{WBC}_{\mathrm{s}}$, this was in agreement with Alkattan ( 2006 ) in laying hens and Salah , ( 2008 ) in broiler breeder males .Campbell ( 1995 ) showed a negative significant correlation between $\mathrm{WBC}_{\mathrm{s}}$ and lymphocytes $\%$ and Salah ( 2008 ) showed a positive significant correlation between $\mathrm{WBC}_{\mathrm{s}}$ and heterophils \%, as a result, all these effect, were reflected in the improvement of stress index due to the fenugreek treatment .

Table 2: Effect of Fenugreek seeds on some biochemical parameters in broiler breeders male serum.

\begin{tabular}{|l|c|c|c|c|}
\hline \multicolumn{1}{|c|}{ Treatments } & $\begin{array}{c}\text { WBCs } \\
\text { thousand } / \mathrm{mm}^{3}\end{array}$ & $\begin{array}{c}\text { Heterophils } \\
\%\end{array}$ & $\begin{array}{c}\text { Lymphocytes } \\
\%\end{array}$ & $\begin{array}{c}\mathrm{H} / \mathrm{L} \\
\%\end{array}$ \\
\hline Control & $17379.33^{\mathrm{a}} \pm 272.75$ & $25.88^{\mathrm{a}} \pm 0.85$ & $65.33^{\mathrm{b}} \pm 1.09$ & $39.11^{\mathrm{a}} \pm 1.71$ \\
\hline $\begin{array}{l}\text { Fenugreek } \\
\text { once weekly }\end{array}$ & $17358.67^{\mathrm{a}} \pm 263.05$ & $24.66^{\mathrm{a}} \pm 0.70$ & $66.22^{\mathrm{b}} \pm 0.95$ & $36.66^{\mathrm{ab}} \pm 1.42$ \\
\hline $\begin{array}{l}\text { Fenugreek } \\
\text { twice weekly }\end{array}$ & $17582.00^{\mathrm{a}} \pm 234.61$ & $23.00^{\mathrm{b}} \pm 0.74$ & $66.77^{\mathrm{b}} \pm 0.92$ & $34.00^{\mathrm{b}} \pm 1.43$ \\
\hline $\begin{array}{l}\text { Fenugreek } \\
\text { Daily }\end{array}$ & $17500.22^{\mathrm{a}} \pm 251.93$ & $19.44^{\mathrm{c}} \pm 0.83$ & $72.33^{\mathrm{a}} \pm 0.86$ & $26.44^{\mathrm{c}} \pm 1.51$ \\
\hline
\end{tabular}

In regard to the biochemical parameters, fenugreek treatments causes a reduction in glucose levels which reach the significancy in the $3^{\text {rd }}$ and $4^{\text {th }}$ groups, and significant decrease in cholesterol level in the $4^{\text {th }}$ group , and a significant reduction in triglycerides levels in the $2^{\text {nd }}, 3^{\text {rd }}$ and $4^{\text {th }}$ groups as compared with control.( Fig 1 $, 2,3)$.

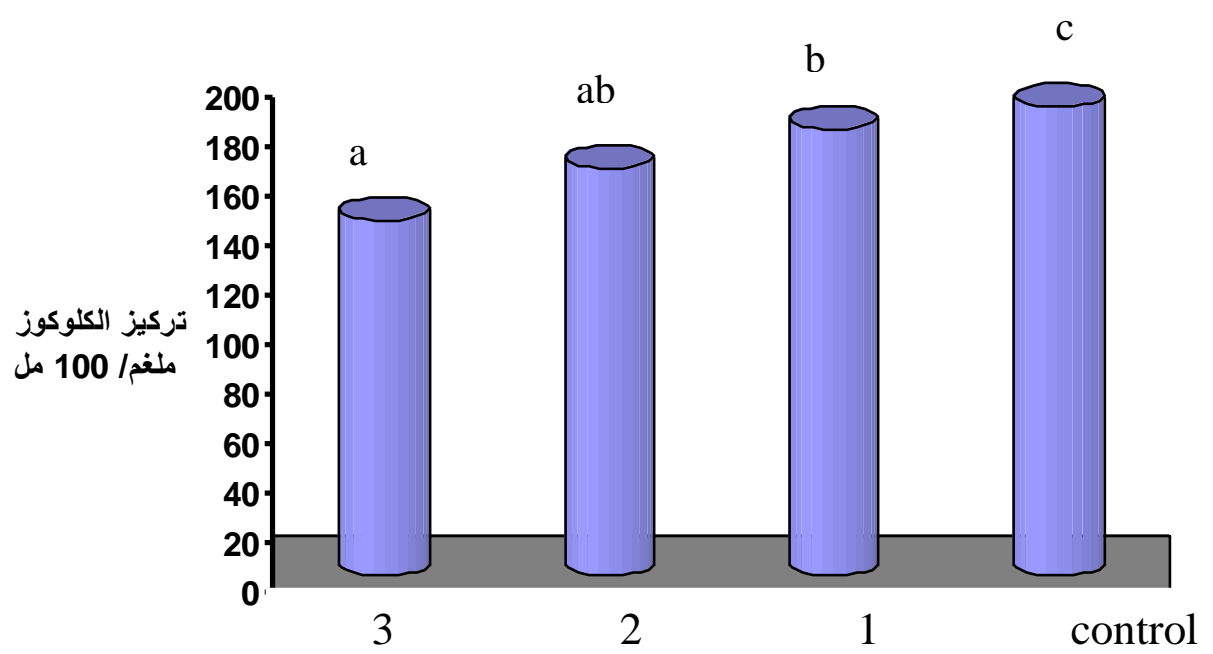

Fig (1): effect of fenugreek seeds on glucose concentration $(\mathrm{mg} / 100 \mathrm{ml})$ in broiler breeders . 


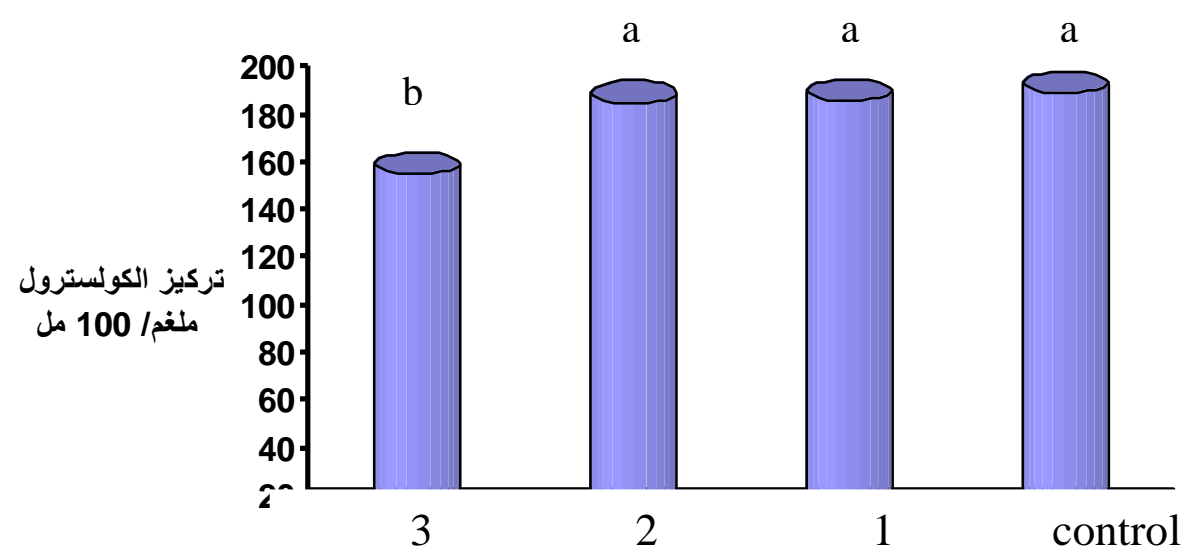

Fig (2) : effect of fenugreek seeds on cholesterol concentration $(\mathrm{mg} / 100 \mathrm{ml})$ in broiler breeders .

The hypoglycemic effect of fenugreek was in agreement with other studies like Abdul - Majeed ( 1994 ) and Al - Niumi ( 1999 ) in broilers, and Alkattan ( 2006 ) in laying hens, this hypoglycemic ability may belongs to the

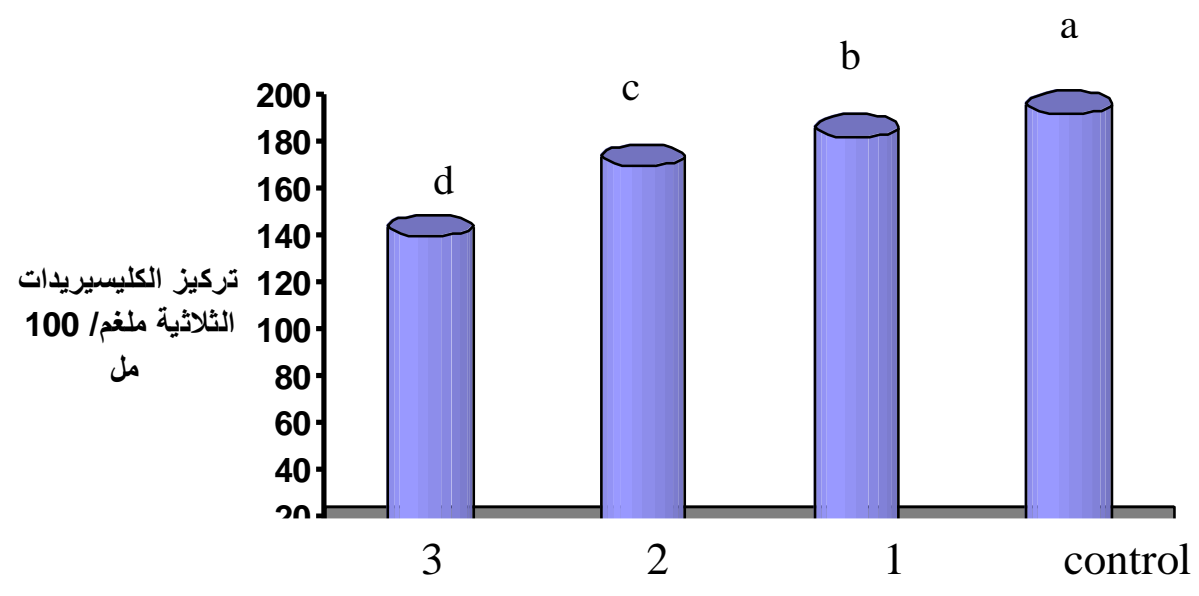

Fig (3) : effect of fenugreek seeds on Triglycerides concentration ( $\mathrm{mg} / 100 \mathrm{ml})$ in broiler breeders .

pectins in the fenugreek seeds which delay the stomach empting and so delays glucose absorption from intestine ( Ali etal .,1995 ), also Heafele etal., ( 1997 ) revealed that the fenugreek seeds possess the enzyme Dioxygenase which activate the production of 4 - Hydroxyisoleucine the later activate insulin secretion and so the glucose level will be reduced .Pectin also inhibit lipid absorption ( Cara etal., 1992 ) Fenugreek seeds contain Saponins and resins ( Cheij,1984 ) which inhibit bile acids and cholesterol absorption from intestine ( Uchida etal.,1984 ), Saponin forms non absorbable complexes with bile and cholesterol in the intestinal lumen and prevent its absorption (Petit etal .,1995) , so that, liver will change more 
cholesterol into bile acids and this will reflected in the reduction of serum cholesterol level .

In conclusion, the present study revealed that fenugreek seeds treatment can improve some blood parameters that may elongate the productive age of broiler breeder males and improve their reproductivity.

\section{تاثير بذور الحلبة في بعض الصفات الفسلجية لذكور امهات فروج اللحم \\ الخلاصة}

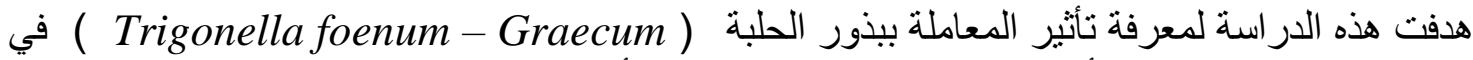

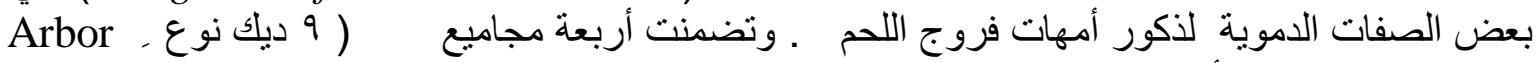
( Acers ا - السيطرة تناولت العليقة القياسية

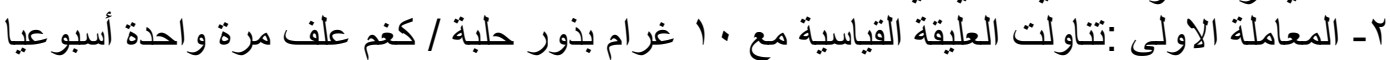

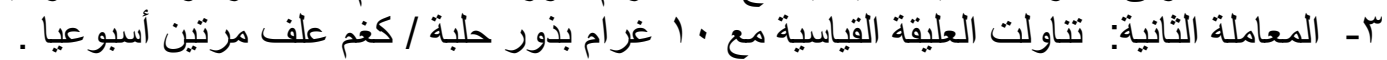

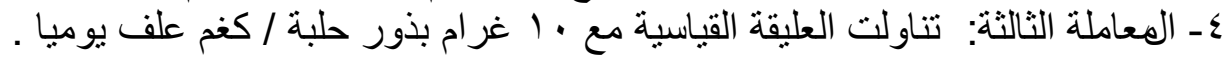

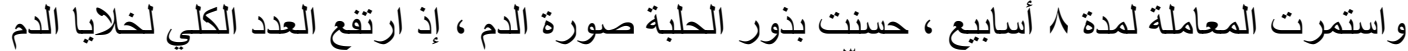

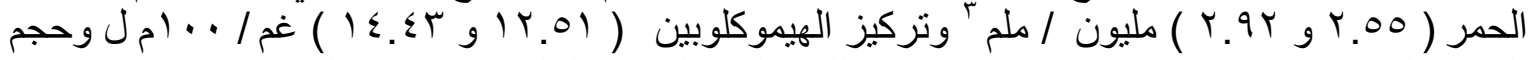

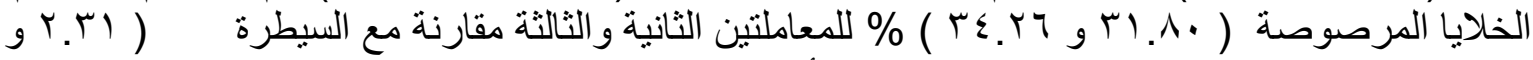

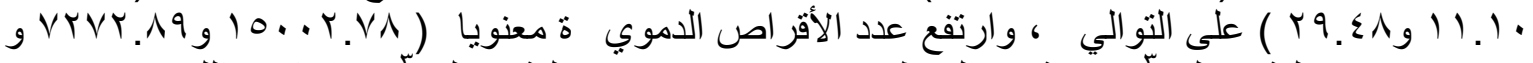

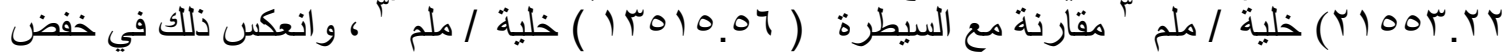

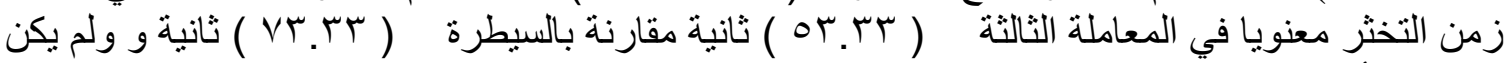
للمعاملة تأثير في العدد الكلي لخلايا الدم البيض ، وانخفضت نسانة نسة الخلايا المتغايرة معنويا في المعاملتين $r$ r

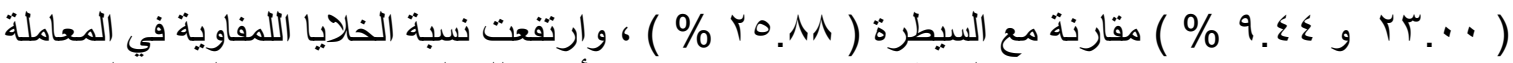

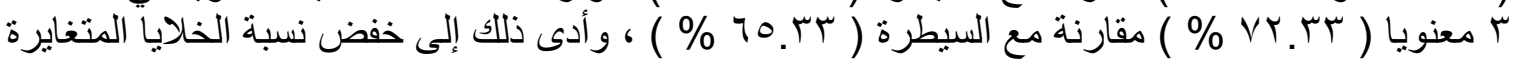

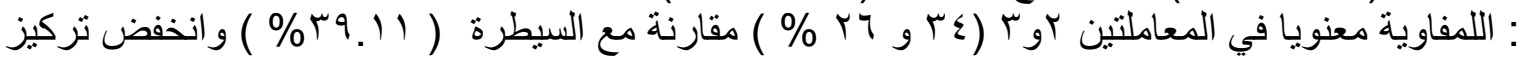

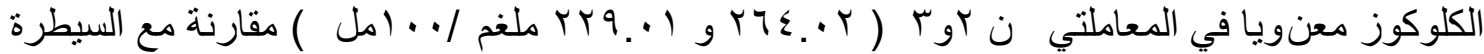

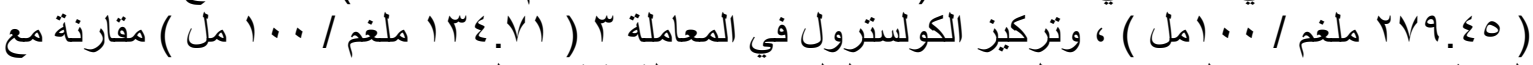

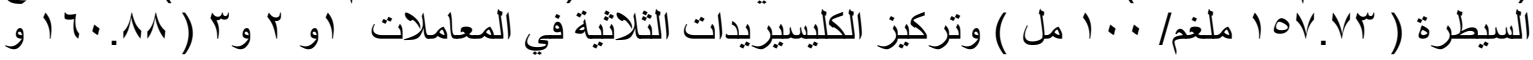

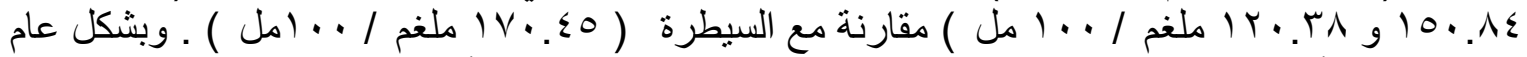

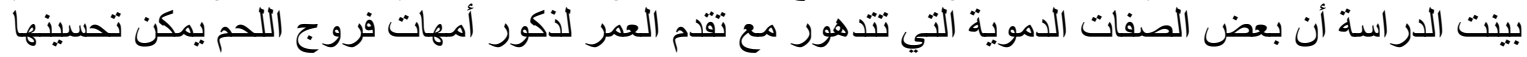

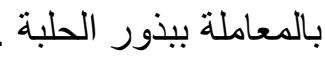

\section{References}

Anonymous.( 2002 ). Statistical Analysis Systems. Software, v.9, SAS Institute, Cary, NC.

Anonymous. (1994) . (National Research Council) . Nutrient Requirement Of Poultry (9th Revisited National Academy Press, Washington D.C.

Abdul - Majeed., A. F ( 1994). Effect Of Hypoglycemic Plants On Some Physiological \& Biochemical Parameters In Broiler Chicken. MSc thesis , College of Veterinary Medicine , University of Mosul

Abdul - Rahman, S., Y. and ,R. N. Alobaidy. ( 2012). Effect of Fenugreek seeds and Olive leaves on some physiological characters of laying breeder hens. Accepted for publishing, Mesopotamia Journal of Agriculture. 
Abdul - Rahman, S., Y. and Alkattan, M. M.(2006) . Effect of using olive leaves in fatty liver syndrome in laying hens. The $4^{\text {th }}$ Scientific conference Veterinary College , University of Mosul. PP: $507-515$.

Abdul - Rahman, S., Y., Sultan., K. H and Taha., A. T.( 2010). The effect of fenugreek seeds on the reproductive performance of aged broiler breeder males. Journal of Tikrit University for Agricultural Sciences. 10 (2) : 156 163.

Alkattan., M. M.,(2006). Effect of Using Some Antioxidants on Production Performance and Some Physiological Characters in Laying Hens. PhD. Thesis, College of Agriculture and forestry, University of Mosul .

Al- Niumi., S. M.,(1999). Effect Of Hypoglycemic Plants On Some Physiological \& Biochemical Parameters And Feed Efficiency In Broiler Chicken. MSc thesis , College of Agriculture and forestry, University of Mosul

Ahmed., N. N and S, S. Mohammad., ( 2012). Effect of using Fenugreek seeds and Olive leaves on some reproductive characters of laying breeder males and females , Accepted for publishing, Mesopotamia Journal of Agriculture.

Alobaidy.,R. N. ( 2012). Effect Of Fenugreek Seeds And Olive Leaves Ration Supplementation On Productive And Physiological Performance Of Laying Breeder Hens ( Isa Brown),Msc Thesis , College of Agriculture and forestry, University of Mosul .

Ali , Azadkhan , A.K. Hassan , Z. , Mosihuzzaman , M. , Nahae , N. , Nasreen T. , Nur-e-Alam , M. and B. Bokeya , (1995). Characterization of the hypoglycemic effects of Trigonella foenum - graecum seed . Planta Med. 61 :358-360 .

Betteridge, D.J. ( 2000 ). What is oxidative stress . Metabolism , clinical and experimental, $49: 3-8$.

Bhat , B.G. , Sambaiah , K. and N. chadrasekhara (1985) . The effect of feeding fenugreek and ginger on bile composition in the albino rats . Nutr. Rep. Int. $32: 1145-1151$.

Campbell . T . W . ( 1995 ) Avian Hematology and Cytology .2 ${ }^{\text {nd }}$. Ed. A Blackwell Publishing Company Lowa State Press .

Cara, L ., Dobis , C. , Borel, P. , Armand , M. , Senft, M., Portugal , H. , Pauli, A . M ., Bernard, P. M. and D. Lairon , (1992) .Effects of oat bran. rice bran, wheat fiber, and wheat germ on postprandial (Lipidemia in health adult. Am, J. Clin. Nutr. $55: 81-88$.

Cheij R. (1984) McDonald Encyclopedia Of Medical Plants . McDonald and Co.,(publishers) Ltd, London, pp. : 209,309 , 313.

Erin , AN; Spirin , M.M ; Tabidze .L. V.and V.E. Kagan. ( 1984 ).Formation of $\infty$ tecopherol complexes with fatty acids. Ahypothetical Mechanism Of Stabilization Of Biomembranes By Vitamin E . Biochem .Biophys. Acta.774:96 - 102

Gonzalez , A. J . M; Oporta , M.E.S; Pro - Martinez , A and Y.C. Lopezcoello , ( 2000 ).Feed restriction and salbutamol to control a scitis syndrome in broilers productive performance and carcass trails . Publicado Como Articulo en Agrociencia .34 : 283 - 292 . 
Heafele C. , Bonfils C. , Y. Sauvaire (1997) characterization of a dioxygenase from Trigonella foenum - graecum involved in 4- hydroxy Isoleucine synthesis phytochemistry . (Abstract) 44 (4) . 563 .

Jain , N . ( 1986 ) .Schalm's Veterinary Hematology Lea and Febiger . USA . 267 282 .

Jain ,S.K. ( 1989 ) . The neonatal erythrocyte and its oxidative susceptibility .Seminars in Hematology . $26: 268-300$.

Mohammad., S, S. ( 2012). Effect Of Fenugreek Seeds And Olive Leaves In Aged Laying Breeder Hens ( Isa Brown) Reproductive Performance ,MSc Thesis , College of Agriculture and forestry, University of Mosul.

Petit , P. , Sauvaire , Y. , Hillaire - buys, D. , Leconte , O.M. , Baissac , Y., Ponsin , G. and Ribes , G. (1995) . Steroid saponins from Fenugreek seeds : Extraction, purification, and pharmacological investigation on feeding behavior and plasma cholesterol. Steroids . $60: 674-680$.

Taha., A. T.(2008). The Role of Vitamins A ,C and Fenugreek Seeds in Lowering Oxidative Stress Effect on Physiological and Reproductive Performance of Males Broiler Breeder. PhD. Thesis, College of Agriculture and forestry, University of Mosul .

Saeed, J. M.(1998). Stress effect on semen production \& some blood traits in local cocks. Iraqi, Journal of Veterinary Medicine.11. (2) : $105-113$.

Saif , Y . M ; Barnes , H .J; Fadly,A.M;Glisson,J.R; Mc Dougald , L.R and Swagne ,D.E.( 2003 ) Disease of poultry, $11^{\text {th }}$ Edition .Lowa state press .Blackwell Publishing Company . USA .

Siegal, H.S.( 1980 ) . Physiological stress in birds . Bio . Sci . 30 : 529 - 534 .

Sturkie , P.D. ( 2000 ) .Avian physiology .Fifth Edition .Edited by G. Causey Whittow.

Surai ,P. F., E. Blesbois, I. Grasseau, T. Ghalag J-P Brillard G. Wishart, S. Cerolini andN. H. C. Sparks.(1998). Fatty acid composition, glutathione peroxidase and superoxide dismutase activity and total antioxidant activity of avian semen .Comp. Biochem . Physiol. 120B: 527-533.

Uchida , K. , Takasa , H. , Nomura , Y. et al. (1984) . changes in biliary and fecal bile acids in mice after treatments with diosgenin and B- sitosterol . J. Lipid Res. $25: 236$.

Wepruk, J . and S . church ( 2003 ) . Balancing production and welfare . Complex animal Care issues . Alberta Farm Animal Care ( AFAC ). Association . 2 8 . 